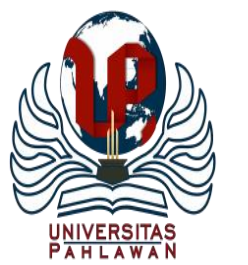

Edukatif : Jurnal Ilmu Pendidikan Volume 3 Nomor 1 Tahun 2021 Halm 227 - 234 EDUKATIF: JURNAL ILMU PENDIDIKAN

Research \& Learning in Education

https:/ledukatif.org/index.php/edukatif/index

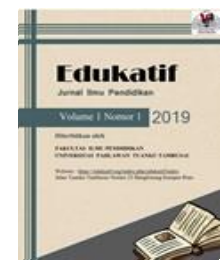

\title{
Studi Komparatif Model Problem Solving dengan Model Teams Games Tournament (Tgt) terhadap Hasil Belajar Matematika Siswa Sekolah Dasar
}

\author{
Suardin $^{1 凶}$, Wa Ode Lisa Andriani ${ }^{2}$ \\ Universitas Muhammadiyah Buton, Indonesia ${ }^{1,2}$ \\ E-mail : suardinmuh78@ gmail.com ${ }^{1}, \underline{\text { wolisaandriani @ gmail.com }}^{2}$
}

\begin{abstract}
Abstrak
Rendahnya nilai hasil belajar matematika siswa kelas V (lima) di SDN 1 Katilombu menuntut perlunya formulasi dan penerapan model-model pembelajaran yang efektif meningkatkan hasil belajar siswa. Tujuan penelitian ini yaitu untuk mengetahui perbedaan hasil belajar matematika antara yang menggunakan model pembelajaran Problem Solving dan Model Pembelajaran Teams Games Tournament (TGT), siswa kelas V SD Negeri 1 Katilombu Kabupaten Buton Selatan. Jenis penelitian ini yaitu quasi experimental design dengan pendekatan deskriptif kuantitatif, dan menggunakan analisis data deskriptif dan inferensial untuk melihat nilai perbandingan hasil belajar matematika. Hasil penelitian diperoleh bahwa berdasarkan uji t test dua sampel independen diperoleh nilai rata - rata kelas VA sebesar 68,13 dengan nilai signifikansi 0,00 dan kelas VB sebesar 79,59 dengan nilai signifikansi 0,00 . Karena nilai sig (2-tailed) $0,00 \leq 0,05$, maka dinyatakan bahwa ada perbedaan yang signifikan antara nilai rata - rata hasil belajar siswa pada kelompok eksperimen I (VA) dan kelompok eksperimen II (VB). Dengan demikian dapat disimpulkan bahwa penggunaan model pembelajaran Teams Games Tournament (TGT) dapat meningkatkan hasil belajar siswa pada mata pelajaran matematika di kelas V SD Negeri 1 Katilombu, dengan nilai rata-rata lebih tinggi dibanding model pembelajaran problem solving.
\end{abstract}

Kata Kunci: Komparasi, Model Problem Solving, Team Games Tournament, Hasil Belajar, Matematika.

\begin{abstract}
The poor learning outcomes of fifth grade students at SDN 1 Katilombu in mathematics implies the need for formulation and implementation of effective learning models to improve students' learning outcomes. The purpose of this study is to determine the differences of learning outcomes in mathematics using Problem Solving learning model and the Teams Games Tournament (TGT) learning model on the fifth grade students of SD Negeri 1 Katilombu, South Buton Regency. This research used quasi experimental design with a quantitative descriptive approach, descriptive and inferential data analysis to see the comparative value of mathematics learning outcomes. The results showed that based on the two independent sample t test, the mean value of the VA class was 68.13 with a significance value of 0.00 and the VB class was 79.59 with a significance value of 0.00 . Because the sig (2-tailed) value of $0.00 \leq 0.05$, it is stated that there is a significant difference between the mean value of students' learning outcomes in the experimental group I (VA) and the experimental group II (VB). Thus it can be concluded that the use of the Teams Games Tournament (TGT) learning model can improve students' learning outcomes in mathematics in grade V SD Negeri 1 Katilombu, with an average score higher than the problem solving learning model.
\end{abstract}

Keywords: Comparisons, Problem Solving, Team Game Tournaments, Learning Outcomes, Mathematics.

Copyright (c) 2021 Suardin, Wa Ode Lisa Andriani

$\triangle$ Corresponding author

Email : suardinmuh78@gmail.com

DOI : https://doi.org/10.31004/edukatif.v3i1.289

ISSN 2656-8063 (Media Cetak)

ISSN 2656-8071 (Media Online) 
229 Studi Komparatif Model Problem Solving dengan Model Teams Games Tournament (Tgt) terhadap Hasil Belajar Matematika Siswa Sekolah Dasar - Suardin, Wa Ode Lisa Andriani

DOI: https://doi.org/10.31004/edukatif.v3i1.289

\section{PENDAHULUAN}

Usaha mewujudkan cita-cita pendidikan nasional, dibutuhkan proses pembelajaran yang berkualitas dengan mendayagunakan segala sumber daya dan komponen pendidikan. Salah satu komponen pendidikan yang utama adalah tenaga pendidik atau guru. (Mariyana, 2010) menjelaskan bahwa salah satu sumber daya yang berada dalam ruang lingkup pendidikan yang harus dikelola dan dikembangkan secara berkesinambungan adalah guru. Setiap guru senantiasa harus mampu menjadikan dirinya sebagai sumber pengetahuan, keterampilan, dan kemampuan yang terakumulasi dalam cita-cita pendidikan. Guru efektif dapat mengaktifkan energi siswa untuk bekerja menuju tatanan sosial yang lebih adil dan manusiawi. Guru yang berdedikasi tinggi dan terampil mengajar, membantu meningkatkan kompetensi dan meraih tujuan siswanya. Sedangkan guru yang terampil dalam melaksanakan tugas profesional mengajarnya, menciptakan pembelajaran yang mampu merangkul pengalaman belajar siswa mengenai bagaimana gagasan dan emosi berinteraksi dengan susasana kelas, keduanya dapat berubah sesuai suasana yang juga turut berubah (Sagala, 2012).

Demikian pula halnya dalam pembelajaran matematika dibutuhkan keterampilan, dan kreatifitas tertentu bagi guru. Terlebih lagi bagi siswa sekolah dasar, matematika merupakan modal dasar bagi peserta didik dalam mengembangkan pola pikirnya ke jenjang pendidikan selanjutnya dan menghadapi realitas hidup di lingkunganya. Oleh karena itu, guru sedapat mungkin mewujudkan pembelajaran matematika yang aktif, inovatif, kreatif, efektif, dan menyenangkan, sehingga tidak lagi diasumsikan sebagai pelajaran yang sulit dan menakutkan bagi siswa.

Berdasarkan hasil wawancara dengan guru wali kelas V di SD Negeri 1 Katilombu Kabupaten Buton Selatan, diperoleh informasi bahwa hasil belajar mata pelajaran matematika pada siswa kelas V Sekolah Dasar Negeri 1 Katilombu Kabupaten Buton Selatan, sebagian besar masih berada di bawah nilai kriteria ketuntasan minimum (KKM) $(6,5)$ yaitu sebanyak 56\% dari total jumlah siswa masih memperoleh nilai matematika yang berada pada kategori tidak tuntas. Salah satu pokok bahasan yang masih di bawah standar KKM adalah materi Kelipatan Persekutuan Terkecil dan Faktor Persekutuan Terbesar dengan Faktor Prima (KPK DAN FPB). Dari hasil observasi lapangan, dijumpai proses pembelajaran yang masih menerapkan model pembelajaran konvesional, di mana transformasi pengetahuan berpusat pada guru, siswa hanya sebagai pendengar, peran serta dan kemandirian siswa dalam interkasi pembelajaran menjadi pasif. Keadaan inilah yang menjadi penyebab utama rendahnya hasil belajar siswa, di samping faktor-faktor lainnya. Keadaan ini perlu segera diatasi dengan melakukan pembaharuan model pembelajaran yang lebih berorientasi pada keaktifan belajar siswa.

Beberapa model pembelajaran yang dapat digunakan untuk meningkatkan interaksi dan pengalaman, dan hasil belajar siswa. Nurulawati dalam (Shoimin, 2014) menjelaskan bahwa model pembelajaran adalah kerangka konseptual yang melukiskan prosedur yang sistematis dalam mengorganisasi pengalaman belajar untuk mencapai tujuan belajar tertentu, dan berfungsi sebagai pedoman bagi para perancang pembelajaran dan pengajar dalam merencanakan aktivitas belajar mengajar. Problem Based Instruction membuat peserta didik terlibat lebih aktif dalam proses pembelajaran untuk memecahkan masalah yang dikaitkan dengan pengetahuan yang sudah diperoleh peserta didik (Desnarita, 2019). Model problem solving adalah model pembelajaran yang dapat menstimulasi peserta didik dalam berpikir kritis, dimulai dari mencari data hingga mengambil makna sampai merumuskan kesimpulan dari kegiatan pembelajaran" (Shoimin, 2014). Model pembelajaran TGT (Team Games Tournament) adalah salah satu model pembelajaran kooperatif yang melibatkan aktivitas seluruh siswa tanpa adanya perbedaan status, melibatkan peran siswa sebagai tutor sebaya dan mengandung unsur permainan dan reinforcement. Aktivitas siswa dengan model TGT 
230 Studi Komparatif Model Problem Solving dengan Model Teams Games Tournament (Tgt) terhadap Hasil Belajar Matematika Siswa Sekolah Dasar - Suardin, Wa Ode Lisa Andriani

DOI: https://doi.org/10.31004/edukatif.v3i1.289

memungkinkan siswa dapat belajar lebih rileks disamping menumbuhkan tanggung jawab, kerjasama, persaingan sehat dan keterlibatan belajar (Gayatri, 2009).

Untuk meningkatkan interkasi dan hasil belajar siswa dalam penelitian ini, digunakan model pembelajaran problem solving dan TGT. Penerapan model-model pembelajaran ini diharapkan agar siswa mampu berpikir tingkat tinggi, kritis, kreatif dan mandiri, yang pada akhirnya dapat meningkatkan hasil belajar siswa materi Kelipatan Persekutuan Terkecil dan Faktor Persekutuan Terbesar dengan Faktor Prima (KPK DAN FPB). Penelitian ini bertujuan untuk: (1) mengetahui hasil belajar matematika siswa kelas V SD Negeri 1 Katilombu Kabupaten Buton Selatan dengan menggunakan model pembelajaran Problem Solving, (2) mengetahui hasil belajar matematika siswa kelas V SD Negeri 1 Katilombu Kabupaten Buton Selatan dengan menggunakan model Teams Games Tournament (TGT), dan (3) mengetahui perbedaan antara hasil belajar matematika siswa yang menggunakan Model Pembelajaran Problem Solving dengan Model Pembelajaran Teams Games Tournament (TGT) siswa kelas V SD Negeri 1 Katilombu Kabupaten Buton Selatan.

Febriana \& Indarini (2020) menyatakan bahwa model pembelajaran problem solving adalah suatu cara menyajikan pelajaran dengan mendorong siswa untuk mencari dan memecahkan suatu masalah atau persoalan dalam rangka pencapaian tujuan pengajaran. Alipandie (Kristiawan et al., 2017) problem solving adalah cara mengajar yang dilakukan dengan cara melati siswa menghadapi berbagai masalah untuk dipecahkan sendiri atau bersama-sama. Model Problem Solving adalah penggunaan model dalam kegiatan pembelajaran dengan jalan melatih siswa menghadapi berbagai masalah baik itu masalah pribadi/perorangan maupun masalah kelompok untuk dipecahkan sendiri atau secara bersama-sama (Prasetya \& Ahmadi, 2005). Model Problem Solving adalah model pembelajaran yang melakukan pemusatan pada pembelajaran dan keterampilan pemecahan masalah diikuti dengan penguatan keterampilan"(Muhlisrarini, 2014). Penerapan Problem Solving akan dapat mengembangkan kemampuan berpikir rasional siswa, yaitu kemampuan menganalisis situasi, menerapkan kemampuan yang dimiliki dalam situasi baru, kemampuan untuk memecahkan masalah, serta memahami hubungan antar apa yang dipelajari dengan kenyataan dalam kehidupannya (Sanjaya, 2016). Tujuan dari penggunaan model Problem Solving yaitu peserta didik mampu memahami masalah sesuai dengan kaidah ilmiah dan langkah langkah berpikir kritis (Suyanto \& Jihad, 2013: 124). Sementara itu Hodiyanto (2017: 227) menjelaskan bahwa Kemampuan komunikasi matematis siswa yang diajarkan dengan model pembelajaran problem solving lebih baik dari pada kemampuan komunikasi matematis siswa yang diajarkan dengan model pembelajaran langsung.

Dapat disimpulkan bahwa model pembelajaran problem solving adalah model pembelajaran yang melatih kemampuan dan keterampilan berpikir kritis siswa, melalui aktivitas mencari informasi, menganalisis situasi, mengidentifikasi masalah dengan tujuan untuk menghasilkan alternatif pemecahannya, dan dapat mengambil suatu tindakan/keputusan untuk mencapai tujuan pembelajaran serta mampu mengkomunikasikan atau menghubungkan hubungan antar apa yang dipelajari dengan kenyataan dalam kehidupannya.

Thompson, dalam (Isjoni, 2014) mengemukakan bahwa pembelajaran kooperatif turut menambah unsur-unsur interaksi sosial pada pembelajaran. Dalam pembelajaran kooperatif siswa belajar bersama dalam kelompok-kelompok kecil yang saling membantu satu sama lain. Kelas disusun dalam kelompok yang terdiri dari 4-6 orang dengan kemampuan yang heterogen, campuran perbedaan kemampuan siswa, jenis kelamin, dan suku, sehingga melatih siswa menerima perbedaan dan bekerja sama dengan teman yang berbeda latar belakangnya. (Isjoni, 2014) menjelaskan bahwa model pembelajaran kooperatif tipe TGT merupakan salah satu tipe pembelajaran kooperatif yang menempatkan siswa dalam kelompok-kelompok belajar yang beranggotakan 4-6 orang siswa yang memiliki kemampuan, jenis kelamin dan ras yang berbeda". TGT menggunakan turnamen akademik dan kuis-kuis serta sistem skor kemajuan individu, dimana peran siswa berlomba sebagai wakil timnya dengan anggota tim lain yang kinerja akademik sebelumnya yang setara 
231 Studi Komparatif Model Problem Solving dengan Model Teams Games Tournament (Tgt) terhadap Hasil Belajar Matematika Siswa Sekolah Dasar - Suardin, Wa Ode Lisa Andriani

DOI: https://doi.org/10.31004/edukatif.v3i1.289

(Slavin, 1980). TGT adalah salah satu tipe pembelajaran kooperatif yang menempatkan siswa dalam kelompok-kelompok belajar yang beranggotakan 5-6 siswa dengan kemampuan, jenis kelamin, dan suku atau ras yang berbeda (Rusman et al., 2012).

Hidayah \& Leonard (2013) menguraikan langkah-langkah pembelajaran TGT yakni: (1) Tahap penyajian kelas, meliputi; presentasi kelas dimana guru memberikan penjelasan kepada para siswa tentang materi yang akan dipelajari, dapat dilakukan dengan tanya jawab kepada siswa atau menugaskan siswa untuk mengerjakan soal di papan tulis; (2) Tahap kerja tim/kelompok, meliputi; pembentukan kelompok, pemberian tugas untuk dikerjakan siswa dengan menekankan kerjasama semua anggota tim. Jika ada anggota tim yang belum menguasai materi, maka anggota lain bertugas membantunya; (3) Tahap permainan (Games) yakni permainan akademik menggunakan kartu soal, masing-masing kartu mempunyai skor yang berbeda tergantung pada tingkat kesukaran soal pada kartu soal, dan kelompok yang menyelesaikan game dengan cepat dan benar adalah pemenangnya; (4) Tahap Tournament (Kompetisi) yakni pengelompokkan siswa dalam kemampuan serupa mewakili tiap timnya. Kompetisi ini merupakan sistem penilaian kemampuan perorangan dan memungkinkan siswa dari semua level untuk memaksimalkan nilai kelompoknya menjadi terbaik dari penampilan sebelumnya. Turnamen biasa diselenggarakan akhir minggu, setelah guru membuat presentasi kelas dan kelompok yang mengerjakan tugasnya; (5) Tahap penghargaan kelompok (Team Recognnition), yakni di akhir permainan guru mengumumkan kelompok pemenang, dengan memberikan sertifikat atau hadiah jika rata-rata skor memenuhi kriteria yang tentukan. Kelompok mendapat julukan "Super Team" jika rata-rata skor 50 atau lebih, "Great Team" bila rata-rata mencapai 50-40, dan "Good Team" bila rata-rata 40 ke bawah.

Dapat disimpulkan bahwa model team games tournament (TGT) merupakan salah satu model pembelajaran kooperatif dimana setiap anak dikelompokkan kedalam kelompok-kelompok kecil beranggotakan 4 sampai 6 siswa yang berbeda tingkat kemampuanya, jenis kelamin, dan latar belakang etniknya, dilaksanakan mengandung unsur permainan dan turnamen akademik serta penghargaan, sehinga proses belajar mengajar berjalan lebih efektif dan tidak membosankan.

\section{METODE PENELITIAN}

Metode penelitian pada dasarnya merupakan cara ilmiah untuk mendapatkan data dengan tujuan dan kegunaan tertentu (Sugiyono, 2015). Jenis penelitian yang digunakan pada penelitian ini yaitu Quasi Experimental Design. Desain ini mempunyai kelompok kontrol, tetapi tidak dapat berfungsi sepenuhnya untuk mengontrol variabel-variabel luar yang mempengaruhi pelaksanaan eksperimen. Populasi penelitian ini yaitu seluruh siswa kelas V SD Negeri 1 Katilombu yang terbagi 2 kelas dengan jumlah 44 siswa. Adapun sampel dalam penelitian ini adalah siswa kelas VA sebanyak 22 orang sebagai kelompok eksperimen I dan kelas VB sebanyak 22 orang sebagai kelompok eksperimen II. Data penelitian dikumpulkan dengan menggunakan teknik tes dan observasi. Data dihimpun saat pra, proses dan setelah memberikan perlakuan (treatment) pembelajaran matematika dengan menerapkan model pembelajaran Problem Solving untuk kelompok eksperimen I, dan model pembelajaran Teams Games Tournament (TGT) untuk kelompok eksperimen II. Tes akhir untuk mengetahui hasil belajar peserta didik. Data hasil penelitian diolah dengan menggunakan dua teknik, yaitu analisis deskriptif dan analisis inferensial.

Analisis statistik deskriptif digunakan untuk mendeskripsikan hasil belajar matematika yang dipeoleh dari kedua kelas eksperimen dengan menggunakan SPSS 18.0 for window. Data tes dianalisis secara deskriptif dengan menggunakan persentase $(\%)$ melalui rumus: 
232 Studi Komparatif Model Problem Solving dengan Model Teams Games Tournament (Tgt) terhadap Hasil Belajar Matematika Siswa Sekolah Dasar - Suardin, Wa Ode Lisa Andriani

DOI: https://doi.org/10.31004/edukatif.v3i1.289

$$
\mathrm{P}=\frac{f}{N} \mathrm{x} 100 \%
$$

Keterangan:

$\mathrm{P}=$ Angka persentase

$\mathrm{f} \quad=$ Frekuensi yang sedang dicari persentasenya

$N=$ Banyaknya sampel responden

Statistik Inferensial digunakan untuk menguji hipotesis penelitian yang diajukan untuk mengetahui apakah ada perbedaan antara model pembelajaran Problem Solving dengan model pembelajaran Teams Games Tournament terhadap hasil belajar matematika siswa Kelas V SD Negeri 1 Katilombu Kabupaten Buton Selatan. Adapun tahapan analisis yang digunakan adalah sebagai berikut:

a. Uji Normalitas: digunakan untuk mengetahui normalitas distribusi data, menggunakan uji normalitas dalam independen T Test. Untuk uji normalitas independen T Test digunakan uji Shapiro Wilk dan Liliefors. Pengujian normalitas dilakukan dengan menggunakan bantuan SPSS versi 18.0. Keputusan hasil analisis uji normalitas ditetapkan dengan kriteria: (1) Apabila nilai sig $>0,05$ maka data tersebut berdistribusi normal; (2) Apabilah nilai sig $<0,05$ maka data tersebut berdistribusi tidak normal.

b. Uji Homogenitas: digunakan untuk pengujian terhadap kesamaan beberapa bagian sampel yakni seragam tidaknya variansi sampel-sampel yang diambil dari populasi yang sama. Menggunakan uji homogenitas dalam independen t test. Untuk uji homogenitas independen t test, menggunakan bantuan SPSS versi 18.0. Keputusan hasil analisis uji homogenitas ditetapkan dengan kriteria: (1) Apabila nilai sigLevene's Test $>0,05$ maka data tersebut dikatakan homogen; (2) Apabila nilai sigLevene's Test $<0,05$ maka data tersebut dikatakan tidak homogen.

c. Uji Hipotesis; digunakan untuk mengetahui dugaan sementara yang dirumuskan dalam hipotesis penelitian dengan menggunakan uji hipotesis dalam independen sample $\mathrm{T}$ Test. Pengujian hipotesis dilakukan dengan SPSS. Adapun dasar pengambilan keputusan ditetapkan dengan kriteria; Jika nilai sig. (2-tailed) $\leq 0,05$ maka terdapat perbedaan yang signifikan antara hasil belajar pada kelompok eksperimen I (VA) dan kelompok eksperimen II (VB).

\section{HASIL DAN PEMBAHASAN}

Penerapan Model pembelajaran Problem Solving pada kelompok eksperimen I (Kelas VA) SD Negeri 1 Katolimbu, materi Kelipatan Persekutuan Terkecil dan Faktor Persekutuan Terbesar dengan Faktor Prima (KPK DAN FPB), dilaksanakan dengan langkah-langkah utama yaitu: (1) guru memberikan permasalahan materi pembelajaran, (2) siswa melakukan identifikasi permasalahan materi pembelajaran, (3) siswa mengemukakan pendapat/ide dan data untuk menetapkan alternatif solusi/jawaban, (4) siswa berdiskusi, bekerjasama, dan berbagi imformasi untuk mengklarifikasi pendapat/ide, kosep dan data dalam usaha menemukan dan menetapkan solusi/jawaban, (5) siswa memperesentasikan hasil kerjanya, (6) guru bersama siswa melakukan refleksi atas kontribusi/aktifitas setiap siswa dalam pembelajaran.

Hasil analisis data hasil belajar siswa menunjukkan bahwa nilai rata-rata matematika kelompok eksperimen I (VA) SD Negeri 1 Katilombu, dengan menggunakan model pembelajaran Problem Solving 68,14 pada nilai post-test yang berada pada ketegori tinggi 31,8 \%. Hal ini karena proses pembelajaran problem solving menekankan siswa untuk memecahkan masalah Kelipatan Persekutuan terkecil dan Faktor Persekutuan Terbesar dengan Faktor Prima (KPK DAN FPB). Siswa juga mampu memecahkan masalah pembelajaran sesuai dengan kenyataan yang ada di lingkungan siswa dengan pengetahuan baru yang 
233 Studi Komparatif Model Problem Solving dengan Model Teams Games Tournament (Tgt) terhadap Hasil Belajar Matematika Siswa Sekolah Dasar - Suardin, Wa Ode Lisa Andriani

DOI: https://doi.org/10.31004/edukatif.v3i1.289

ditemukan secara berkelompok dan diskusi yang memacu siswa lebih giat belajar. Selain itu juga dapat mendorong siswa berani mengungkapkan pendapatnya. Akan tetapi pada saat proses pembelajaran ini sebagian siswa masih acuh tak acuh pada proses pembelajaran dan lebih mengharapkan ketua kelompok saja yang mencari informasi dari masalah yang diberikan sehingga pemahaman siswa kurang.

Penerapan Model pembelajaran TGT pada kelompok eksperimen II (Kelas VB) SD Negeri 1 Katolimbu, materi Kelipatan Persekutuan Terkecil dan Faktor Persekutuan Terbesar dengan Faktor Prima (KPK DAN FPB), dilaksanakan dengan langkah-langkah pokok yaitu: (1) guru memberikan penjelasan materi pelajaran, selanjutnya memberikan tugas soal-soal kepada siswa untuk dikerjakan di papan tulis, guna mengidentifikasi tingkat pemahaman siswa; (2) guru membentuk kelompok siswa dan memberikan tugas materi pelajaran untuk dikerjakan dengan menekankan kerjasama semua anggota kelompok; (3) guru mengarahkan siswa yang mampu menyelesaikan tugas pembelajaran untuk menjadi tutor bagi siswa yang belum paham; (4) guru memberikan kartu soal untuk bahan permainan (game) siswa dimana masing-masing kartu mempunyai skor yang berbeda sesuai tingkat kesukaran soal, dan menjelaskan aturan-aturan permainan; (5) guru mengelompokkan siswa yang memiliki kemampuan sama untuk mewakili kelompoknya masingmasing, sesuai presentasi kelas dan kelompok yang mengerjakan tugasnya (dilakukan di akhir pertemuan materi); (6) guru mengumumkan kelompok pemenang, dan memberikan hadiah bagi kelompok yang memperoleh rata-rata skor memenuhi kriteria yang tentukan.

Hasil analisis data hasil belajar siswa menunjukkan nilai rata-rata matematika kelompok eksperimen II (VB) SD Negeri 1 Katilombu, dengan menggunakan model pembelajaran Teams Games Tournament 79,59 pada nilai post-test yang berada pada kategori sangat tinggi 40,8\%. Hal ini dikarenakan proses pembelajaran Teams Games Tournament yang diterapkan ditekankan pelibatan siswa secara keseluruhan tanpa harus ada perbedaan status dan kemampuan. Selain itu pula melibatkan peran siswa sebagai tutor sebaya kepada siswa yang belum memehami materi, dan digunakan tournament akademik dimana siswa berkompetisi sebagai wakil dari timnya melawan anggota tim yang lain, selanjutnya tim yang menang diberikan hadiah sehingga menyenangkan para siswa atas hasil capaiannya.

Selanjutnya dilakukan pengujian hipotesis, namun terlebih dahulu dilakukan uji normalitas dan uji homogenitas untuk melihat distribusi normalitas data hasil belajar matematika dan melihat apakah kedua kelompok berasal dari populasi yang homogen atau tidak. Berdasarkan hasil analisis uji normalitas dalam independen $t$ test dengan uji Shapiro Wilk dan Lilliefors bahwa nilai signifikan untuk kelompok eksperimen I (VA) model pembelajaran Problem Solving sebesar 0.234 dan untuk kelompok eksperimen II (VB) model pembelajaran Teams Games Tournament sebesar 0.289. Karena signifikansi kelompok eksperimen I (VA) dan II (VB) lebih besar dari 0,05 (0.234>0,05 dan $0.289>0,05)$ maka disimpulkan bahwa data pada kedua kelompok eksperimen terhadap hasil belajar berdistribusi normal. Uji homogenitas untuk melihat homogenitas tidaknya suatu varians yang diperoleh dianalisis deskriptif menggunakan uji homogenitas dalam independen $t$ test dengan uji Levene's Test diketahui bahwa nilai signifikan pada homogenitas kelompok eksperimen I (VA) dan kelompok eksperimen II (VB) adalah 0.840. Maka dapat dirtikan bahwa varians data antara kelompok eksperimen I (VA) dengan kelompok eksperimen II (VB) adalah homogen atau sama.

Berdasarkan uji t test dua sampel independen diperoleh nilai rata-rata kelas VA sebesar 68.13 sedangkan nilai signifikanya 0,00 dan kelas VB sebesar 79.59 sedangkan nilai signifikanya 0,00 . Karena nilai sig (2-tailed) $0,00 \leq 0,05$, Dengan demikian dapat disimpulkan bahwa ada perbedaan yang signifikan (nyata) antara rata - rata hasil belajar siswa pada kelompok eksperimen I (VA) dan kelompok eksperimen II (VB). Maka sebagai mana dasar pengambilan keputusan dalam independen sample t test jika nilai sig. (2-tailed) $\leq$ 0,05 terdapat perbedaan yang signifikan antara hasil belajar pada kelompok eksperimen I (VA) dan kelompok eksperimen II (VB). Sehingga dapat dikatakan bahwa dengan menggunakan model pembelajaran Teams Games Tournament dapat meningkatkan hasil belajar siswa pada mata pelajaran matematika di kelas V SD 
234 Studi Komparatif Model Problem Solving dengan Model Teams Games Tournament (Tgt) terhadap Hasil Belajar Matematika Siswa Sekolah Dasar - Suardin, Wa Ode Lisa Andriani

DOI: https://doi.org/10.31004/edukatif.v3i1.289

Negeri 1 Katilombu. Hal ini sejalan dengan temuan hasil penelitianSaragih \& Wedyawati (2019) yang menjelaskan bahwa penerapan model pembelajaran TGT dapat meningkatkan hasil belajar siswa.

Dari deskripsi hasil belajar di atas, menunjukan bahwa penerapan model pembelajaran TGT lebih baik dibanding penerapan model pembelajaran problem solving dalam meningkatkan rata-rata hasil belajar matematika materi Kelipatan Persekutuan Terkecil dan Faktor Persekutuan Terbesar dengan Faktor Prima (KPK DAN FPB). Hal ini berbeda dengan temuan penelitian Sarbia et al. (2017) yang menyatakan bahwa penerapan model pembelajaran PBL memberikan hasil lebih baik dibandingkan model pembelajaran Kooperatif TGT dalam kemanpuan pemecahan masalah matematika.

Perbedaan hasil belajar antara problem solving dan TGT dalam penelitian ini, lebih disebabkan oleh beberapa hal yaitu: kesesuaian materi pembelajaran dengan model TGT yakni materi Kelipatan Persekutuan Terkecil dan Faktor Persekutuan Terbesar dengan Faktor Prima (KPK DAN FPB); perbedaan proses pembelajaran yang berimplikasi pada pengalaman belajar siswa, dimana pada proses pembelajaran problem solving masih terdapat sebagian siswa yang tidak aktif dan tidak ada stimulus khusus yang diberikan, sementara pada pembelajaran TGT seluruh siswa terlibat secara aktif dengan penuh gairah dan daya saing antar kelompok karena adanya hadiah/penghargaan bagi kelompok tim pemenang. Selain itu, juga lebih disebabkan pada penguatan tutor sebaya; dimana siswa lebih rileks, mudah dan percaya diri menyerap materi pembelajaran terutama bagi siswa yang masih memiliki kesulitan belajar, karena selain mendapatkan penjelasan dari guru juga mendapatkan bantuan pendampingan/penjelasan dari teman sejawatnya selama diskusi kelompok berlangsung. Inilah penyebab nilai rata-rata siswa pada kelas eksperimen II lebih tinggi dibandingkan dengan kelas eksperimen I, dan sekaligus menjadi keunggulan model pembelajaran TGT dalam penelitian ini. Deskripsi temuan proses pembelajaran dalam penelitian ini sejalan dengan pendapat yang dikemukakan oleh Shoimin (2014) menjelaskan bahwa kelebihan model pembelajaran teams games tournament (TGT) adalah tidak hanya membuat peserta didik yang cerdas (berkemampuan akademis tinggi) lebih menonjol dalam pembelajaran, tetapi peserta didik yang berkemampuan akademi lebih rendah juga ikut aktif dan mempunyai peranan penting dalam kelompoknya. Lebih jelas diuraikan sebagai berikut; (1) dengan model pembelajaran ini, akan menumbuhkan rasa kebersamaan dan saling menghargai sesama anggota kelompok; (2) dalam model pembelajaran ini, membuat peserta didik lebih bersemangat dalam mengikuti pelajaran. Karena dalam pembelajaran ini, guru menjanjikan sebuah penghargaan pada peserta didik atau kelompok terbaik; (3) dalam pembelajaran peserta didik ini, membuat peserta didik menjadi lebih senang dalam mengikuti karena ada kegiatan permainan berupa turnament dalam model ini.

\section{SIMPULAN}

Hasil belajar matematika, siswa kelas V SD Negeri 1 Katilombu dapat dideskripsikan bahwa: Hasil belajar kelompok eksperimen I (kelas VA) yang menggunakan model pembelajaran Problem Solving diperoleh nilai rata-rata 68,14 pada nilai post-test berada pada ketegori tinggi 31,8\%; Hasil belajar kelompok eksperimen II (kelas VB) yang menggunakan model pembelajaran Teams Games Tournament diperoleh nilai rata-rata 79,59 pada nilai post-test berada pada kategori sangat tinggi 40,8 \%; Terdapat perbedaan yang signifikan antara hasil belajar siswa yang menggunakan model pembelajaran Problem Solving dengan hasil belajar siswa yang menggunakan model pembelajaran Teams Games Tournament, dimana nilai rata-rata kelompok yang diberi perlakuan model pembelajaran Problem Solving lebih rendah dibandingkan dengan kelompok yang diberi perlakuan dengan model pembelajaran Teams Games Tournament, hal itu dapat dilihat dari nilai sig (2-tailed) 0,00 lebih kecil atau sama dengan $0,05(0,00 \leq 0,05)$. 
235 Studi Komparatif Model Problem Solving dengan Model Teams Games Tournament (Tgt) terhadap Hasil Belajar Matematika Siswa Sekolah Dasar - Suardin, Wa Ode Lisa Andriani

DOI: https://doi.org/10.31004/edukatif.v3i1.289

\section{DAFTAR PUSTAKA}

Desnarita. (2019). Jurnal basicedu. Jurnal Basicedu, 3(2), 524-532.

Febriana, T., \& Indarini, E. (2020). Komparasi Pembelajaran Problem Based Learning (PBL) dan Problem Solving terhadap Kemampuan Berpikir Kritis Matematis Siswa Sekolah Dasar. Jurnal Basicedu. https://doi.org/10.31004/basicedu.v4i4.494

Gayatri, Y. (2009). Cooperative Learning Tipe Team Game Tournaments ( Tgt ) Sebagai Alternatif Model Pembelajaran Biologi. Didaktis, 8, 59-67.

Hidayah, A. A., \& Leonard. (2013). Penggunaan Metode Problem Posing Dalam Proses Pembelajaran Matematika. Majalah Ilmiah Faktor.

Hodiyanto, H. (2017). Pengaruh Model Pembelajaran Problem Solving Terhadap Kemampuan Komunikasi Matematis Ditinjau dari Gender The Effect of Problem Solving Learning Model Toward Mathematical Communication Ability Viewed from Gender. 4(2), 219-228.

Isjoni. (2014). Cooperative Learning efektifitas pembelajaran kelompok. In Bandung: Alfabeta.

Kristiawan, M., Safitri, D., \& Rena Lestari. (2017). Manajemen Pendidikan. Deepublish.

Mariyana, R. (2010). Etika Profesi Guru. Etika Profesi Guru.

Muhlisrarini, A. H. D. (2014). Perencanaan Dan Strategi Pembelajaran Matematika. Rajagrafindo Persada Jakarta.

Prasetya, J. T., \& Ahmadi, A. (2005). Strategi belajar mengajar. Bandung: CV.

Rusman, Maftukhin, A., \& Nurhidayati. (2012). Pemanfaatan model snowball throwing untuk meningkatkan keaktifan belajar ipa pada siswa kelas VIII E SMP Negeri 22 Purworejo. Radiasi.

Sagala, S. (2012). Konsep dan Makna Pembelajaran: Untuk Membantu Memecahkan Problematika Belajar dan Mengajar. In Bandung: Alfabeta.

Sanjaya, A. (2016). Landasan Teori. Landasanteori.Com.

Saragih, E., \& Wedyawati, N. (2019). Penerapan Model Pembelajaran TGT Untuk Peningkatan Hasil Belajar Materi Bilangan Romawi Siswa Kelas IV Sekolah Dasar. Riemann: Research of Mathematics and Mathematics Education. https://doi.org/10.38114/riemann.v1i1.10

Sarbia, Busnawir, \& Sudia, M. (2017). Pengaruh Model Pembelajaran Problem based learning ( PBL ) Dan Model Pembelajaran Kooperatif TGT Terhadap Kemampuan Pemecahan Masalah Matematik Berdasarkan Self Regulated Learning Siswa SMP. 8(1), 86-96.

Shoimin, A. (2014). 68 Model Pembelajaran Inovatif dalam Kurikulum 2013. In AR-RUZZ MEDIA.

Slavin, R. E. (1980). Cooperative Learning. Review of Educational Research. https://doi.org/10.3102/00346543050002315

Sugiyono, P. D. (2015). Metode Penelitian Pendidikan Sugiyono 2015 BAGIAN 3. In Penerbit AlphaBeta. 